\title{
On the Amateur and the Critic and the Double Factoring of the Pandemic ${ }^{1}$
}

Virgilio A. Rivas

\begin{abstract}
This essay explores Bernard Stiegler's reformulation of Kant's aesthetics concerning his radical concept of the amateur vis-àvis the critic. These conflicting agencies have staked out different modalities and forms of engagement and resistance against the broader historical background of what Stiegler calls the proletarianization of sensibility drawn from the experience of today's algorithmic governance. COVID-19 has rendered this global technicalization of experience more insidious. Or, invoking Derrida, the grammatization of the subjects' gestures and behavior, making their protentional capacity and their power to dream inoperable through pre-selected aprioris for social consumption, or worse, biopolitical control. Stiegler identifies the radical promise of exposing this techno-determinism with the amateur's unprincipledness, whose non-conformism, compared to the critic, the conventional expert, draws more from the autonomous function of art. In this context, the amateur aligns herself with the worker in terms of their capacity to dis-individuate from the manifold, leading to a common approach to the pharmacology of the Spirit. Pharmacology stands for the relative plasticity of a specific historical time, not without the pathogen that troubles its metastability - its openness to critique. Nonetheless, the task of unraveling this pathogenic content can no longer be assigned to the critical subject of reason.
\end{abstract}

Keywords: amateur, anthropological break, archival metaphysics, critic

${ }^{1}$ I am grateful to Prof. Joff P.N. Bradley of Teikyo University, a well-published scholar of Stiegler (and Deleuze studies), for his ideas, comments, and suggestions to the initial draft of this paper. Prof. Bradley is the editor of Educational Philosophy and Theory where my article on Stiegler appeared. See Virgilio A. Rivas, "Stiegler and the Task of Tertiary Retention: On the Amateur as an Educational Subject," in Educational Philosophy and Theory, $<$ https://doi.org/10.1080/00131857.2021.1897569>.

(c) 2021 Virgilio A. Rivas

https://www.kritike.org/journal/issue 29/rivas december2021.pdf

ISSN 1908-7330

(c) BY-NC-ND 


\section{Introduction}

7 he following set of reflections divides into two sections and a concluding segment. The first deals with the broader form of categorizing two conflicting concepts, the amateur and the critic, which we designate as bearers of protentional technicity in line with Stiegler's reformulation of the Kantian aesthetic from which these concepts are drawn. The second section discusses the directional components of the amateur's disposition towards present-day reality amid the long "anthropological break" 2 that Stiegler associates with posthumanism. ${ }^{3}$ However, this uncanny form of historico-temporal cessation is redoubled by COVID-19, as it were, intruding on the human species' uncertain path.

In the course of our brief discussions, it will come to light that the amateur possesses a keen eye to counter-factual realizations specific to her complicated predisposition to pharmacology, burdened by the paradox of "double epohkhal redoubling." ${ }^{4}$ Moreover, the amateur exhibits a creative attitude towards truth claims that she proposes by her capable fictions, innovative assemblies of truth contents, which, arguably enough, uncover the same plasticity of imagination as informs the tenacity of rational proofs. The amateur pursues truth claims by "supporting...a test" without the certainty of "ever being able to be proven." 5 The test otherwise evidences the nonprovable by "making it shared," a supportable economy of free exchange, "[opening] a public space and time that are the exact opposite of an

\footnotetext{
${ }^{2}$ Bernard Stiegler, "Elements for a General Organology," trans. by Daniel Ross, in Derrida Today, 13 (2020), 73.

3 Stiegler sketches his idea of posthumanism in line with the concept of the anthropological break: "[A]n internal rearrangement and reorganization of organisms that continues what has already occurred at the industrial level with GMOs and nanomaterials ... everything of which the transhumanist movement is seizing hold." Stiegler, "Elements for a General Organology," 76. Stiegler associates this rearrangement with the "process of interiorization" (Ibid.), which implies a more intensive internalization of technicity in the organic spheres of life. This further implies a "break" from the previous process of externalization in terms of "augmenting [organic life] with non-living organs," the extension of "somatic organs" forming an independent technical life (Ibid., 82). The new phase of interiorization thus engenders a new organology, the way humans, with the aid of technical systems and objects, organize inorganic matter that fuses with bodies, environments, systems, etc., creating a new assemblage, a biotechnical life; overall, an epiphylogenetic evolution still in the process of completion. In this sense, organology is the "organic form of technical life" (Ibid., 75). Yuk Hui, in a separate work, underlines this organological aspect in terms of breaking the "illusion" that "human beings [are] mere observers and machines [are] replacements for human beings." See Yuk Hui, Recursivity and Contingency (London and New York: Rowman \& Littlefield, International, 2019), 274. Bracket emphases mine.

${ }^{4}$ Bernard Stiegler, Nanjing Lectures: 2016-2019, trans. by Daniel Ross (London: Open Humanities Press, 2020), 337.

${ }^{5}$ Bernard Stiegler, "Kant, Art, and Time," in boundary 2, 44 (2017),33.
} 


\section{ON THE AMATEUR AND THE CRITIC}

audience." 6 The concept of the audience operates in an enforceable epistemic equation where the critic, the supposed expert who wields rational authority, imparts knowledge to the audience for wider social consumption.

Accordingly, the critic as an expert enjoys a broader communication platform at the behest of the organs of power, the same organs of power that require accelerationist metrics for standardization of learning outputs, ${ }^{7}$ for instance; a key global uniformity instrument in the age of speed, digital precision, and algorithmic control. Shoshana Zuboff, in The Age of Surveillance Capitalism, argues against the same atrocious demand of speed and its quasimoral imperative (the same line of contestation as Paolo Bolaños' in a slightly earlier criticism of performance metrics) "demanding that we relinquish individual agency to the automated systems that can keep up the pace." 8 However, the technical demand for precision and speed tends to override the psycho-noetic experience of time and space (which is bound to the finitude of human experience). In terms of its resonance in educational practices, this results in the operational surveillance of education, already being absorbed into a standardized performance ranking system, pitting institutions and individuals in their "programmed relations" to "algorithmic governmentality." 9 As Stiegler asserts, "[t]hese programmed relations give rise to dividuation in Guattari's sense, that is, to the destruction of individuation." 10 Suffice it to say, education itself co-constitutively "shapes the social field" upon which multiple, intersectional conflicts are "played out." 11 This aspect of social contamination by epistemic spaces of reason brings to mind the effect education can have on the distribution of the sensible. ${ }^{12}$ This pre-individual field of knowledge formations is practically and socially cognizable, referring to the manifold cognates through which we are always

${ }^{6}$ Ibid., 32.

7 I am referring to Paolo Bolaños's discussion of Paul Virilio's critique of speed capitalism and its relation to higher education's rush to quantify academic and curricular performance. See Paolo Bolaños, "Speed and Its Impact on Education," in INQUIRER.net (30 October 2019), $<$ https://opinion.inquirer.net/124900/speed-and-its-impact-on-education>.

${ }^{8}$ Shoshana Zuboff, The Age of Surveillance Capitalism: The Fight for A Human Future at the New Frontier of Power (New York: Public Affairs, 2019), 442

9 See Thomas Berns and Antoinette Rouvroy, "Algorithmic Governmentality and Prospects of Emancipation," trans. by Elizabeth Libbrecht, in Réseaux, 177 (2013).

10 Bernard Stiegler, Automatic Society. Vol. 1. Future of Work, trans. by Daniel Ross (Cambridge: Polity Press, 2016), 66.

11 See Torin Monahan and Rodolfo D. Torres, "Schools Under Surveillance," in Surveillance Studies: A Reader, ed. by Torin Monahan and David Murakami Wood (Oxford: Oxford University Press, 2018), 206.

12 Yves Citton, "Political Agency and the Ambivalence of the Sensible," in Jacques Rancière: History, Politics, Aesthetics, ed. by Gabriel Rockhill and Philip Watts, 120-139 (Durham and London: Duke University Press, 2009).

(c) 2021 Virgilio A. Rivas

https://www.kritike.org/journal/issue 29/rivas december2021.pdf

ISSN 1908-7330

(cc) BY-NC-ND 
already, albeit provisionally, "known" and "in knowing,"13 which enable their plasticity for social enforcement. Education performs conflicting functions derived from dividuating complexities of private and social interests impinging on individual and collective autonomy in favor of the anonymous freedom of technics. However, more than the accelerationist implication for education, state power "internalizes the opposition between manual workers and intellectuals." Hence, as Stiegler asserts elsewhere, "there would be specialists of the intellect, and therefore of thinking, and then there would be everyone else." 14 Roughly speaking, this is how the modern university was born.

The concluding section will then underscore the amateur's critical role in public education in the face of the ongoing pandemic and the larger question of the incomplete history of the technicalization of organic life, as Stiegler described in one of his last known works before his untimely death in $2020 .{ }^{15}$ He called it the general organology of life, "no longer just biological but technical" and "involves not just organic matter but organized inorganic matter." 16 The correlation of technicity and COVID-19 is crucial: the twin rationalizations of the pandemic and the massive technicalization of experience have strained planetary life in ways never before seen in modern humanity's history. In a sense, the pandemic is the most recent organological strain on this history, "[riding] on the larger evolutionary scale, mediated in part by culture, by law, by technology; and even on the cosmopolitan philosophy held by modern nation states." 17

\section{The Amateur and the Critic: Two Faces of the Subject}

On the one hand, in line with the logic and semantics of the subject, the figure or image of the critic conveys a self-repetitive, recursive purchase: The subject is the object of the externalization of the I or the ego for purposes of knowing and doing. We are referring to the self-reflexive principle from

\footnotetext{
13 Or, what Kant calls the "manifold of empirical intuitions." See Immanuel Kant, "Transcendental Logic," in Critique of Pure Reason, trans. by Werner Pluhar (Indianapolis and Cambridge: Hackett Publishing Company, Inc., 1996), B219, 248.

14 Bernard Stiegler, Neganthropocene, ed. and trans. by Daniel Ross (London: Open Humanities Press, 2018),180-181.

${ }^{15}$ Stiegler elaborates on this aspect of organology inspired by Gilbert Simondon: "In technical life, the relationship between the organic and the organological is what Simondon calls transductive: in technical life, the organic is originally constituted in its very organicity by the organological, and vice versa - the organological is inherently constituted by the organic form of technical life. In other words, in technical life, the organic cannot be thought without the organological, and vice versa." Stiegler, Elements for a General Organology," 74-75.

${ }^{16}$ Ibid., 72.

${ }^{17}$ Jeffrey P. Bishop and Martin J. Fitzgerald, “Norming COVID-19: The Urgency of NonHumanist Holism," in The Heythrop Journal (2020).
} 


\section{ON THE AMATEUR AND THE CRITIC}

which the subject orients itself in thought and the world. ${ }^{18}$ Stiegler alerts us to the nuanced, complicated rulebook of critical reason started by Kant, concerning its primary agent, the critic who, Stiegler contends, "can always still lapse into the status of cultivated philistine." ${ }^{19} \mathrm{He}$ who has supposedly achieved "professional-level mastery," the critic, is the opposite complement of the amateur who, in place of her shortcomings, on the other hand, is defined by her "commitment to passion and desire, by a devotion to becoming." 20

But given the massive automation or, what Stiegler prefers to call the global proletarianization of sensibility, ${ }^{21}$ fueled by the consumerist age, it is no surprise that the all too familiar tools of inventory and analysis since Kant, more so, the supposed reflexivity of the critic (typically a male petitbourgeois) are no less, if not already, coopted, staked and funded by the apparatuses of attention control and capture. This results in mediatized outcomes of the operation of the faculties of reason, including retentional and predictive somatic activities reserved for protentional thinking and experience. In the Kantian sense, this is what the critic precisely performs an inventory of retentional and protentional thoughts and experiences. Yuk Hui, in The Archives of the Future, describes the purpose of this modern inventory as a projection of the assumed certainty of the future, ${ }^{22}$ impacting on the human capacity to select items of retentional nature or "the selection of protentions, which is ... the fabric of experience." ${ }^{23}$ This form of selection via data algorithms involves an atypical notion of spatio-temporality different from Kant's approach. Here the Kantian manifold, initially unformatted (it is up to the understanding to provide the manifold with cognitive structure), gives way to a predetermined inventory, formatted spatio-temporal aprioris that leave nothing to free selection.

The certainty of the archive of the future, or archival metaphysics in Hui's quasi-Derridean lingo, is presently realized in how retentional and protentional practices manifest the irrevocable movement of futurology (or futures metaphysics). The archive of the future has overlaid the presupposition of "the historical conditions for critique ... through familiarity with works that

\footnotetext{
${ }^{18}$ Bernard Stiegler, “The New Conflict of the Faculty and Functions: Quasi-Causality and Serendipity in the Anthropocene," trans. by Daniel Ross, in Qui Parle, 26 (2017).

${ }^{19}$ Bernard Stiegler, "The Quarrel of the Amateurs," trans. by Robert Hughes. boundary 2, 44 (2017), 35

${ }^{20}$ Robert Hughes, “Bernard Stiegler, Philosophical Amateur, or, Individuation from Eros to Philia," in Diacritics, 42 (2014), 61.

${ }^{21}$ Bernard Stiegler, "The Proletarianization of Sensibility," in boundary 2, 44 (2017).

${ }^{22}$ Yuk Hui, Archives of the Future: Remarks on the Concept of Tertiary Protention (Gutenberg: Landsarkivet I Göteborg, 2018), 134.

${ }^{23}$ Stiegler, Neganthropocene, 140.

(c) 2021 Virgilio A. Rivas

https://www.kritike.org/journal/issue 29/rivas december2021.pdf

ISSN 1908-7330
}

(c) BY-NC-ND 
themselves presuppose a practice." 24 Correspondingly, the Kantian subject dissolves into an agent of pre-selected experiences, becomes a pre-selected subject of the algorithmic manifold that it ironically helped create by bestowing an analytical procedure for algorithms to employ with nearperfect precision, ${ }^{25}$ until such time when there is "nothing else" for the critic "to analyze other than his own interest." 26

But the ubiquity of individual interests also deadens the political instinct by dis-ambiguating the political from the collectivity of choice, insofar as "all political questions dissolve into economics," and, as Stiegler very well asserts, "since ideology is no longer about collective choices but about 'individual' relations to products." 27 For Stiegler, the rise of the neoliberal concept of the individual - "when there is nothing more to analyze other than one's own interest" - forms the basis of algorithmic governance or the "ever closer linking of individual needs with functional and ideological programs in which each new product is embedded." 28 Under these conditions, the post-Kantian subject succumbs to the more treacherous side

${ }^{24}$ Stiegler, "Kant, Art, and Time," 22.

25 This started approximately with the Critique of Pure Reason, which, as we know, required the understanding to complete an inventory of its possessions, a task that demanded mastery of the retentional history of reason for purposes of defining the protentional direction of knowledge from hereon.

${ }^{26}$ Stiegler, "The Quarrel of the Amateurs," 36. Or what feminists would interpret as the self-absorbed reflexivity of truth-telling. See Donna Haraway, Modest Witness@Second Millennium. FemaleMan (C_Meets_OncoMouse ${ }^{\mathrm{TM}}$ : Feminism and Technoscience (New York and London, Routledge, 1997), 31.

Contemporary feminists argue that masculine reflexivity burdens the feminist cause by projecting reflexivity when it simply "reinscribes the absent presence of female subjectivity" [Susan Sturman, "On Black-boxing Gender: Some Social Questions for Bruno Latour," in Social Epistemology, 20 (2006), 181]. This example approximates what Stiegler observes of the critic (presumably male) who has nothing else to "analyze" other than his self-positioning rationality. The idea is similar to Bruno Latour's notion of the exhaustion of the energies of critique as when "critique" itself "runs out of steam," when scientific objectivity, for instance, becomes suspect as a "power-laden social construction," thus, can never qualify as universally accepted truth [Matthias Flatscher and Sergej Seitz, "Latour, Foucault, and Post-Truth: The Role and Function of Critique in the Era of the Truth Crisis," in Le foucaldien, 6 (2020), 6]. This leaves the critic in a position of "going through the motions of a critical avant-garde," even though the "spirit is gone" [see Bruno Latour, "Why Has Critique Run out of Steam? From Matters of Fact to Matters of Concern," in Critical Inquiry, 30 (2004), 226]. Ironically, feminists also take Latour to task for another display of male reflexivity. His rejection of science as a social construction in favor of "networks of human and inhuman ecologies" ignores the fact that his "particular masculine subjectivity is produced in the culture of experimental science" [Sturman, "On Black-boxing Gender," 182] where Latour operates. Given these premises, Stiegler may also be liable to gender obscurantism, which, however, is not the scope of this paper to explore beyond identifying the proximity of Stiegler's view of the "critic" vis-à-vis a system that has exhausted its usefulness, thereof withdraws into self-absorption, to contemporary feminist criticism.

${ }^{27}$ Stiegler, Automatic Society, 66.

${ }^{28}$ Ibid. 


\section{ON THE AMATEUR AND THE CRITIC}

of what he proposes to call the "infidelity of the pharmacology of Spirit," 29 where the Spirit is absorbed into the technology of indexing and connecting. ${ }^{30} \mathrm{In}$ capitalistic terms, this results in the "general mediatization of every life," otherwise, a "process of intensified integration into commodity culture." 31 The infidelity that Stiegler assigned to the pharmacology of the Spirit refers to the strictly transitional nature of historical time, where the twin determinations of the "pathological" and "normativity," for instance, "develop according to a new logic." 32 Pharmacology is subject to the individual and collective psycho-noetic contingencies of retentional and protentional thinking and experience. To this extent, the "original pathogenic content" of the Spirit's pharmacology reveals itself in the form of historical, hermeneutic, and transindividual metastability. ${ }^{33}$ Here the significance of the variable nature of the pathogen is that it can be discovered as both a "bond and an illness," 34 thereby stabilizing itself into the "normativity of the living." ${ }^{35}$ It is in consequence of the plasticity of the pathogen, according to Stiegler, what "Canguilhem called normative, and that Plato [originally] called anamnesic"36 (which points to the pathogen's retentional nature), that the Spirit itself becomes open to analysis, adaptation, intervention, even partial elimination. Altogether this is what Stiegler would ascribe to the work of "critique." But algorithms drastically alter this openness to historical critique via "an automated form of social control." ${ }^{37}$ As the Spirit's new configuration, the pathogenic futurology of algorithms seems "inevitable and incurable." 38

This gives us a no-exit scenario in the face of the inevitability of archival metaphysics or the absolute control of organic life in the future. Hui derives this concept from his partial reading of Derrida's différance, bearing the twofold sense of differing and deferring with regards to its integral relation to time:

Derrida proposes here a new theory of the archive based on Freudian psychoanalysis... Derrida explores how the

29 Bernard Stiegler, What Makes Life Worth Living, trans. by Daniel Ross (Cambridge: Polity Press, 2013), 41.

${ }^{30}$ Hui, Archives of the Future, 134.

${ }^{31}$ See Jernej Prodnik, "3C: Commodifying Communication in Capitalism," in Marx in the Age of Digital Capitalism, ed. by Christian Fuchs and Vincent Mosco (Brill: Leiden and London, 2016), 302.

32 Stiegler, What Makes Life Worth Living, 29.

${ }^{33}$ Ibid., 41.

${ }^{34}$ Ibid., 27.

${ }^{35} \mathrm{Ibid} ., 28$. See also Georges Canguilhem, The Normal and the Pathological (New York: Zone Books, 1991), 178.

${ }^{36}$ Stiegler, What Makes Life Worth Living, 123. Bracket emphasis mine.

37 Stiegler, Nanjing Lectures, 15.

${ }^{38}$ Stiegler, What Makes Life Worth Living, 50.

(c) 2021 Virgilio A. Rivas

https://www.kritike.org/journal/issue 29/rivas december2021.pdf

ISSN 1908-7330

(c) $\mathrm{BY}-\mathrm{NC}-\mathrm{ND}$ 
question of the origin leads ultimately to the question of the future ... The origin is always deferred, and, within such a différance, which is found inside the archive itself, a future is opened up. ${ }^{39}$

However, the future as a question, in Stiegler's critique of Derrida, may also unintentionally sink into an "impasse." 40 This happens when one opposes the "anamnesic" (primary retention) to the "hypomnesic" (i.e., the "arrangements of the primary and secondary retentions and protentions ... conditioned by tertiary retentions)," 41 which at present is mediated by technical protocols of indexicality, capable of producing artificial or prosthetic memory qua tertiary retention. For Stiegler, transcendental memory (primary retention, which in Derridean terms, is only a trace of the origin) must not be opposed to transcendental imagination (tertiary retention that, again, presupposes a hypomnesic, generally, organological arrangement); else, it would result in a metaphysics of deferred time, ${ }^{42}$ an undecidable temporality predisposed to fantasizing the origin via its trace. Like Derrida, Stiegler proposes an active form of retroactivity while acknowledging the fact that tertiary retention always already "imposes selection," which lies "at the very heart of anticipation that is already memorization qua forgetting." 43 But retroactivity is also already an actual historical critique, a genealogy, and nosology of the Spirit. Stiegler's quasiDerridean influence would rather that the possibilities for a radical flight/critique are continuously explored but not without embracing a dilemma, which is "to act in a therapeutic manner on a malaise, and to eventually reverse it into a chance to learn." ${ }^{44}$

This spells out Stiegler's concept of pharmacology that Claire Colebrook describes as a radical form of unprincipledness that demands an impossible future, all the more when the task of unraveling the pharmacology of historical time becomes assignable to the amateur. ${ }^{45}$ The amateur here is the post-Kantian, post-Derridean subject whose unprincipled mission is, nonetheless, already familiar, which is to educate. However, the amateur is

\footnotetext{
${ }^{39}$ Hui, Archives of the Future, 133.

40 Stiegler, What Makes Life Worth Living, 19.

${ }^{41} \mathrm{Ibid}$.

42 Bernard Stiegler, Technics and Time. Vol. 1. The Fault of Epimetheus, trans. by Richard Beadsworth and George Collins (Stanford, California: Stanford University Press, 1998), 231.

${ }_{43}$ See Bernard Stiegler, Technics and Time 2: Disorientation, trans. by Stephen Barker (Stanford California: Stanford University Press, 2009), 232.

${ }^{44}$ Benoit Dillet, "Proletarianization, Deproletarianization, and the Rise of the Amateur," in boundary 2, 44 (2017), 94.

${ }^{45}$ Claire Colebrook, "Impossible, Unprincipled, Contingent: Bernard Stiegler's Project of Revolution and Redemption," in boundary 2, 44 (2017), 223.
} 


\section{ON THE AMATEUR AND THE CRITIC}

facing a dual difficulty: 1) the highly mediatized protocols of understanding the manifold defined by attention control and capture, too complex for consciousness to master, or work out an escape route; 2 ) the metaphysics of the differrance-permeated future via the passive directness of the present rendering it perfectly susceptible to the grammatization of experience, in the absence of a firm decision to prevent the future from becoming present. This undecidability creates real-time, an algorithmic time born out of the necessary default's inability to ground an origin, speaking of the transcendental imagination that originates a ground (in the absence of an ontologically pre-existing background). 46 Undecidability engenders a "deferred time," which, as Stiegler contends, "always arrives too late"; hence, when confronted with "this real-time" that overwhelms experience by the monstrousness of its speed, undecidability inevitably "generates a kind of (trap of) automatic quasi-causality." ${ }^{47}$ Indeed, as Colebrook argues, the "audacity of Stiegler's project" lies in the fact that his concept of the "pharmakon functions ... more as a way of achieving a genealogy and nosology of spirit," 48 not an escape route, but a mere, if not useless provocation to disambiguate the infidelity of pharmacology from the "programmed relations" in which it is embedded.

Decisions are always already inventoried in a pre-formatted manifold, such as an archive. Once again, this can be referenced to Derrida: "The quest after the origin, through the preservation of the past, is for Derrida an archive drive, which is another name for what he calls archive fever." 49 In Derridean terms, however, the archive is where the origin is transcendentally lost. The archive can only manifest the drive to preserve the past (not the past, but just the drive) whose différance with the origin (the questioning of the identifiability of the origin's trace) is such that it must always be an origin without a trace. That is the archive itself, a mere "play of traces." 50 Stiegler addresses this impasse by departing from the Derridean problem of infinite regress, emphasizing the historical function of technics in terms of hypomnesic arrangements of systems of retention or memory via the "shift from the transcendental or the quasi-transcendental to an immanent historical (or a-transcendental) analysis of technicity." 51

Given Stiegler's independent study of rhizomatics, it is worth noting in passing that Deleuze and Guattari traced the doctrine of the faculties in the

${ }^{46}$ Stiegler, Automatic Society, 115.

${ }^{47}$ Ibid.

${ }^{48}$ Colebrook, "Impossible, Unprincipled, Contingent," 224-225.

${ }^{49}$ Hui, Archives of the Future, 132.

${ }^{50}$ Jacques Derrida, "Différance," in Literary Theory: An Anthology, 2nd ed., ed. by Julie Rivkin and Michael Ryan (Oxford: Blackwell Publishing, 2004), 289.

${ }^{51}$ Hui, Archives of the Future, 139.

(c) 2021 Virgilio A. Rivas

https://www.kritike.org/journal/issue 29/rivas december2021.pdf

ISSN 1908-7330

(c) $\mathrm{BY}-\mathrm{NC}-\mathrm{ND}$ 
"organs of state Power" 52 whose powerful protential drive to constitute the future broadly relies on the plasticity of tertiary retention that Stiegler assigns to controllability that supervenes on life, labor, and language..$^{53}$ Ideally, the future is made possible by noetic dreaming; the handiwork of a people's imagination, ${ }^{54}$ hijacked, nonetheless, by an all-controlling system of tertiary retention through the "functional overdetermination" of technical objects that possess their own genetic logic and mode of existence and consistency. ${ }^{55}$ This way, the correlation between the doctrine of the faculties and organs of state power becomes blurred.

Overdetermination means occulting the correlation itself, isolating it from the recognizability of the automatization of the fabric of experience through "the technical and social apparatus." 56 For Stiegler, only the amateur can dis-individuate from this correlation, pushing the correlation to betray its secret, which is the enforceable universality of its technical plasticity. This is the universality of state power conveyed by its supposed doctrinal status, which, in Stiegler's reformulation of the Kantian aesthetics concerning the doctrine of the faculties, is only universal "by default." 57 Correspondingly, the comprehensive grammar of the future that selects the contents of individual choices in advance produces a prosthetic audience replacing the subject of critical reason. The invasiveness of algorithms thus contemporizes Stiegler's criticism of the Kantian subject who, as a consequence of indexical archiving, can no longer be "trans-formed by his [own] judgment," but even "in judging, does not trans-individuate (himself)."58 The critic is the diametrical opposite of the amateur who, Stiegler claims, is rather "transformed" by her "love" for works of art. ${ }^{59}$

\section{The Amateur's Automated Ambivalence and COVID-19}

Nonetheless, the amateur (together with the worker) faces the risk of "expulsion" from the social realm's so-called circuits of individuation defined by the grammatization of experience in a twofold scheme: 1) the "grammatization of the gestures of the artist who makes the ordinary extraordinary," on the one hand, and 2) the "grammatization of the behavior of

52 Gilles Deleuze and Felix Guattari, A Thousand Plateaus: Capitalism and Schizophrenia, trans. by, Brian Massumi (Minneapolis, and London: University of Minnesota Press, 1987), 376.

${ }^{53}$ See Michel Foucault, "Labour, Life, Language," in The Order of Things: An Archaeology of the Human Sciences, 272-329 (New York: Routledge, 1989).

54 Stiegler, Automatic Society, 72.

${ }^{55}$ Stiegler, Technics and Time 1, 68.

${ }^{56}$ Stiegler, "The Quarrel of the Amateurs," 46.

${ }^{57}$ Stiegler, "Kant, Art, and Time," 22.

58 Ibid., 25.

${ }^{59}$ Stiegler, "The Proletarianization of Sensibility," 7. 


\section{ON THE AMATEUR AND THE CRITIC}

those who are thereby going to be consumers," ${ }^{60}$ on the other hand. As the artist becomes "swallowed up with the middle class," the amateur becomes a bourgeois. The worker transforms into a proletarian while his "skills are liquidated by consumerism." 61 The combined grammatizations reveal a political realm rendered inoperable by disabling the amateur and the worker of their transformational capacities for individuation, ${ }^{62}$ or worse, by creating mouthpieces as mass provisions out of them in the service of the status quo.

Since the advent of the neoliberal order, technical grammatization has become a system of "autonomized transindividuation," transforming the conduct of reading and writing via the industrial infrastructure of "logical and linguistic automata" 63 in more efficient ways. Incidentally, the COVID19 outbreak pushed this level of grammatization to a new kind of "functional sovereignty." 64 Given the lockdown and quarantine protocols in the early months of the pandemic, the grammatization of responses to the pandemic or the human ability to act under extreme existential threats reached an unprecedented scale. The public, literally shut in their homes, became doubly isolated from the vital question of the political even as they are hooked to technical images reproduced on the internet and mainstream information media, automatically driven to rely on data "formatted in terms of its a priori calculability." 65

The amateur and the worker, both stuck in the perfectly controlled site of algorithmic governmentality, the home, became transformed into able participants of the automatic society's immunological protocols. The internet was singularly investing in reproducing the pandemic's technical images, including professional opinions dependent on formatted aprioris, statistics that science consumed for informed guidance, supervision, and public management. The amateur was caught up in her non-conformist "style," which is supposed to separate her from the pure specialist already estranged from the larger communal sphere. She became the uncanny complement of the expert whose knowledge of the pandemic, nonetheless, became, even worse, more "esoteric for the public," 66 couched in the technical language of epidemiology and data algorithms. (We can hazard that this partly explains the public's indifference toward health protocols, even denying the realities

${ }^{60}$ Stiegler, "The Quarrel of the Amateurs," 49.

${ }^{61} \mathrm{Ibid} ., 47$.

${ }^{62}$ As Vilém Flusser would argue in the same manner, this creates the precise condition for rendering the political critique "inoperable" if not already predetermined "cybernetically." See Vilém Flusser, Post-History, trans. by Rodrigo Maltez Novaes, ed. by Siegfried Zielinski (Minneapolis: Univocal Press, 2013), 90.

${ }^{63} \mathrm{Ibid} ., 233-234$.

${ }^{64}$ Stiegler, Nanjing Lectures, 285.

${ }^{65}$ Ibid., 81.

${ }^{66}$ Stiegler, "The Quarrel of the Amateurs," 44.

(c) 2021 Virgilio A. Rivas

https://www.kritike.org/journal/issue 29/rivas december2021.pdf

ISSN 1908-7330

(c) BY-NC-ND 
of the pandemic, by all indications a derivative of post-truth, claiming that the pandemic is a science conspiracy). The amateur's supposed technical imperfection became even more glaring, in line with the massive algorithmic investment in the virus, giving us a glimpse of how it would shape the immediate future. Algorithmic investment sets its sight on norming the pandemic's futurology in the guise of the new normal, the future archive in the present, which, for Stiegler, signals the "[annihilation] of the play of the amateur," at the same time that this end beckons the "spread of nihilism." 67 The amateur, armed with style, which should define her being more than her technical imperfection, could not get through to the public shut off from the political domain, the psycho-noetic realm of transindividuation, 68 which involves the creative play between inside and outside, interior and exterior. Stiegler likens this political play qua transindividuation to the Deleuzian cinematic movement between two conflicting characterizations, between "traumatypes and stereotypes, individuation and disindividuation," 69 etc.

The viral interregnum. In short, the complexity of the viral interregnum has evolved into the new normal modeled after emergency restrictions or the normalization of control protocols placing health risks (already a biopolitical issue) above any other expressive form of thinking and desiring. The normalization is expected to result, among others, in cheerful "natural" recovery or, what follows, the joint care for the environment, the wildlife, and the planet. This is an example of double epohkhal redoubling: the restraint on freedom that "emergent quarantine ecologies," 70 for instance, unintentionally rationalize could surprisingly lead to nature recovery. However, in her signature style of play, the amateur's task is to convince the public that despite its optimistic message in the face of long-term climate emergency, this emergent ethic is conservatism in disguise. It assumes that nature operates on the independent scheme of self-recovery regardless of the undeniable anthropogenic signature in the conquest of nature. Moreover, this assumption could not have cared less for the human cost of extending utilitarian premises to natural activity. Its rationality lies in ignoring that the positive effect of "quarantine ecologies" is "circumstantial to the pandemic." 71

Suppose, however, that the pandemic itself forms part of the long "anthropological break" or the posthumanist interval we mentioned. In that case, the break, doubly induced by a viral factor, can result either in more

${ }^{67} \mathrm{Ibid} ., 45$

${ }^{68}$ Stiegler, Nanjing Lectures, 222.

${ }^{69}$ Colebrook, "Impossible, Unprincipled, Contingent," 214.

70 Adam Searle and Jonathan Turnbull, "Resurgent Natures? More-than-Human Perspectives on COVID-19," in Dialogues in Human Geography, 10 (2020), 293.

${ }^{71}$ Ibid.

(c) 2021 Virgilio A. Rivas

https://www.kritike.org/journal/issue 29/rivas december2021.pdf

ISSN 1908-7330

(cc) BY-NC-ND 


\section{ON THE AMATEUR AND THE CRITIC}

intensive exteriorization of the species, bodies heavily dependent on technologies and subservient to algorithmic governance, or the "beginning of a new process of interiorization,"72 leading to new, unforeseeable pharmacology. In Posthuman Life: Philosophy at the Edge of the Human, David Roden proposed a concept for this kind of unforeseeable: the disconnection thesis. ${ }^{73}$ Simply put, the disconnection thesis offers a speculative vision of the "before" and the "after" of posthuman emergence. We can take this thesis as an analogy of the anthropological break that Stiegler proposed to describe the present. The "before" is presumably the intensified erosion of humanist essentialism, which corresponds to a specific character of the humaninhuman organology defined by exteriorization. The "after" remains to be borne out aposteriori, ${ }^{74}$ nonetheless, a "not-yet" that is open to speculation. Providing the lenses for this speculation is the ongoing interiorization of technical life, increasingly blurring the distinction between the inside (supposedly human essence) and outside (technical objects as replacements) whose exact breaking point, in terms of the descent of actual posthumans, is, however, no one's Ph.D. The future remains an open game. The viral interregnum may either prolong the anthropological break or expedite its acceleration into alien organology.

Nevertheless, we can also hazard that the pandemic is a supportable proof milieu that Roden stipulates as the requisite for a "theory of humanposthuman difference."75 COVID-19, which is a prelude to more lethal outbreaks in decades to come, may well apply to the "widest" possible condition (the proof milieu) that can "[permit] biological, cultural and technological relations of descent between human and posthuman."76 But here, we can also trace back the conditions for the emergence of the pandemic to hypomnesic assemblies and compositions, past and present, drawing lessons from them to imagine and pursue new approaches to pharmacology. A new normativity for the living that protentionally selects what to seek and what to avoid in terms of our immunological chances as a species indicates that humanity's problems are not metaphysical. This runs counter to Derrida, who was more accustomed to defending that these problems are best served when we interpret them within the metaphysic of deferral.

\section{The Amateur's Protentional Technicity in the Pandemic Age}

\footnotetext{
72 Stiegler, "Elements for a General Organology," 76.

${ }^{73}$ See David Roden, Posthuman Life: Philosophy at the Edge of the Human (London and New York: Routledge).

${ }^{74}$ Ibid., 105.

${ }^{75} \mathrm{Ibid}$.

${ }^{76} \mathrm{Ibid}$.

(c) 2021 Virgilio A. Rivas

https://www.kritike.org/journal/issue 29/rivas december2021.pdf

ISSN 1908-7330
}

(c) BY-NC-ND 
As emphasized, the pandemic provides a dis-covering phase shift, an apocalypse of the ongoing posthumanist break. Among others, this will entail that we are about to witness the nature recovery in question retaining the model of quarantine ecologies in the new normal as the world facsimile of post-lockdown existence or an attempt to get there. (No wonder Latour described the pandemic as a dress rehearsal to the climate battle ahead, an instance of double epohkhal redoubling where nature serves as the fulcrum of futurology, for better or worse). Nature recovery, however, reflects a paternalistic discourse that rationalizes sexist attributes around the epistemic framing of nature and society: the feminine character of nature, on the one hand, and the masculinity of social and political custodianship of her welfare, on the other hand. Moreover, the pandemic will likely be around for an indefinite period, a projected 10-year horizon at the minimum, ${ }^{77}$ clutching on the transitory human movement towards a posthumanist interiorization of organology. It will either prolong the ongoing phase shift of today's organology or hasten its completion towards an unprecedented timescale, not to mention the impending climate catastrophe that may no longer be reversed. In this sense, the entire planet becomes one geocybernetic experiment that feeds on the posthumanist break.

Here we can only hope the amateur (and the worker) will sustain a mode of individuation premised on the vital function of play (yes, play!), at the point where the critical subject becomes overwhelmed by the functional sovereignty of the future archive. At the height of the bourgeoisification of creativity and the consumerism of our age, calculation becomes the rulebook "aiming to realize an 'investment' that partakes of nothing of the aesthetic." 78 Today the figure of the critic exemplifies calculation, he who has so much interest in investing in the system having nothing else to analyze. (Today, this system situates his interest in a post-planetary configuration, which, nonetheless, conceals the changing dynamics of class conflicts but will not vanish even in a Martian colony unless capitalism is dead in the next decade).

Nevertheless, there is a form of investment that takes part in "the current stage of grammatization"79 with as much interest as "love" through "the amateur ... the figure of desire par excellence: the one who loves." 80 She is more interested in becoming rather than being, in desire rather than accomplishment, in sharing instead of possession. The amateur invests in

77 The British Academy projects a 10-year horizon for the long-term impact of COVID19. See The British Academy, "The COVID Decade: understanding the long-term impacts of COVID-19," in The British Academy (2021), <https://www.thebritishacademy.ac.uk/ publications/covid-decade-understanding-the-long-term-societal-impacts-of-covid-19>.

${ }^{78}$ Stiegler, "The Quarrel of the Amateurs," 36.

${ }^{79}$ Ibid., 50.

${ }^{80}$ Stiegler, "Kant, Art, and Time," 32. 


\section{ON THE AMATEUR AND THE CRITIC}

protentional technicity, not as a norm for the future, rather as a condition of play, of transindividuation. Play filters experience by creating broader opportunities for thinking and desiring, without the burden of competing for accomplishments, a scalable idea, a concept, or a publishable summum bonum. Rather, her task is "to assemble a public," a community of lovers, "within the very feeling of the necessary default," 81 that is to say, in the absence of ground or origin except as being oneself-with-others. Algorithmic governmentality seizes this condition of existence from the once unformatted manifold, a democratic and accepting environment, a consensus-based human-inhuman ecology.

Suppose, indeed, the pandemic has worsened the ongoing grammatization of the species through intensified algorithmic governmentality. With COVID-19, we see a pattern of how viruses that have their own consistency can disrupt the linearity of the anthropological break. Arguably, posthumanism requires viral explosions, preferably of the COVID19 magnitude, if not more precarious forms of organic encounter with technical life, in a word, contingency. Contingency secures the process of completing the collective history of humanity and automation in a final system of organology from becoming as rigidly linear as its unhampered acceleration towards irreversible entropy. The posthumanist break even requires extinction as the imagined totality of the complete absence of the conditions for the apocalypse, for dis-covery in its most aleatory sense. Enough for a state of anguish to prevail out of the experience of loss of meaning and purpose, even the conditions for critique, threatening to destroy with finality the general plasticity qua "infidelity" of the pharmacology of Spirit.

But even this existential predicament can maximize its obverse side, which is the prospect of play. Counter-intuitively, the "impossibility of critique" or the impossibility of pre-empting the future archive can be playfully "cultivated" (against contemplative but in light of present-day technical grammatization empty conceptual investments) to accomplish an "improbable possibility instead," 82 to frustrate the linearity of non-critique. This linearity points to the scenario of no exit from the end's certainty since no one is supposed to be ungovernable by hyper-technical grammatization in the postmodern age. In this light, play amounts to "making a decision" - to make the certainty of the future, the archive's totality a "valued part" of organology's incomplete history. ${ }^{83}$ Play makes this incompletion a cherished

${ }^{81}$ Ibid., 33.

82 Stiegler, Neganthropocene, 234.

${ }^{83}$ Cf. Stiegler, "Kant, Art, and Time," 33.

(c) 2021 Virgilio A. Rivas

https://www.kritike.org/journal/issue 29/rivas december2021.pdf

ISSN 1908-7330

(c) $)$ BY-NC-ND 
segment of history. In the manner of Nietzsche and Kafka, play pre-empts history to complete itself. ${ }^{84}$ Play hacks history's codes to become uncodable.

Lastly, instead of the sage, the professional critic of the future archive, or what Bolaños recently termed the "mad professor," 85 play has a way of making the impossible find its true grounding, its improbable possibility, in the loving embrace of the amateur; she who invests in becomings as much as in desiring randomness, and not the predictable results of in-dividuating: becoming-animal, becoming-plant, becoming-mineral. ${ }^{86}$ The amateur: she is the hacker of joy's desire, the desire for imperfection which lies at the heart of her negativity, above all, her capacity for love, the default feeling of shared community, desiring no attribute to complete, no extension to hunt or chase. She is an inverted Spinoza! (if I may). This explains, as Stiegler asserts, the amorous infidelity of her capable fiction of the Spirit:

[W]ithout this fiction there would be no desire. What I love I love without limit, without condition: I cannot love it other than in a manner that is (phantasmatically) unlimited. That which I love and those whom I love, you, that is, us insofar as we are capable of forming a we - all this I love, and I love it (and I love you) infinitely. I love to the infinite. I love only to the infinite, as one says, "to the infinitive." Without which no we is possible. ${ }^{87}$

Department of Philosophy and Humanities
Polytechnic University of the Philippines

\section{References}

Berns, Thomas and Antoinette Rouvroy, "Algorithmic Governmentality and Prospects of Emancipation," trans. by Elizabeth Libbrecht, in Réseaux, 177 (2013).

Bishop, Jeffrey P. and Martin J. Fitzgerald, "Norming COVID-19: The Urgency of Non-Humanist Holism," in The Heythrop Journal (2020).

Bolaños, Paolo, "The Mad Professor," in Kritike: Metaporika Denkbild, 1 (2021).

${ }^{84}$ See Gilles Deleuze, Desert Islands and Other Texts (1953-1974) (New York: Semiotext(e), 2004), 254.

${ }^{85}$ See Paolo Bolaños, "The Mad Professor," in Kritike: Metaporika Denkbild, (2021).

${ }^{86}$ Cf. Felix Guattari, "Becoming Woman," in Chaosophy, trans. by David L. Sweet, Jarred Becker, and Taylor Adkins (Los Angeles, California: Semiotext(e), 2009), 230.

${ }^{87}$ Bernard Stiegler, Acting Out, trans. by Daniel Barison, Daniel Ross, and Patrick Crogan (Stanford, California: Stanford University Press, 2009), 47. 


\section{ON THE AMATEUR AND THE CRITIC}

- "Speed and Its Impact on Education," in INQUIRER.net (30 October 2019), <https://opinion.inquirer.net/124900/speed-and-itsimpact-on-education>.

The British Academy. "The COVID Decade: understanding the long-term societal impacts of COVID-19," in The British Academy (2021), $<$ https://www.thebritishacademy.ac.uk/publications/covid-decadeunderstanding-the-long-term-societal-impacts-of-covid-19>.

Canguilhem, Georges, The Normal and the Pathological (New York: Zone Books, 1991).

Citton, Yves, "Political Agency and the Ambivalence of the Sensible," in Jacques Rancière: History, Politics, Aesthetics, ed. by Gabriel Rockhill and Philip Watts, 120-139 (Durham and London: Duke University Press, 2009).

Colebrook, Claire, “Impossible, Unprincipled, Contingent: Bernard Stiegler's Project of Revolution and Redemption," in boundary 2, 44, 1(2017).

Deleuze, Gilles, Desert Islands and Other Texts (1953-1974) (New York: Semiotext(e), 2004).

Deleuze, Gilles and Felix Guattari, A Thousand Plateaus: Capitalism and Schizophrenia, trans. by Brian Massumi (Minneapolis, and London: University of Minnesota Press, 1987).

Derrida, Jacques, "Différance," in Literary Theory: An Anthology, $2^{\text {nd }}$ edition, ed. by Julie Rivkin and Michael Ryan, 278-299 (Oxford: Blackwell Publishing, 2004).

Dillet, Benoit, "Proletarianization, Deproletarianization, and the Rise of the Amateur," in boundary 2, 44, 1(2017).

Flatscher, Matthias and Sergej Seitz, "Latour, Foucault, and Post-Truth: The Role and Function of Critique in the Era of the Truth Crisis," in Le foucaldien, 6 (2020).

Flusser, Vilém, Post-History, trans. by Rodrigo Maltez Novaes, ed. by Siegfried Zielinski (Minneapolis: Univocal Press, 2013).

Foucault, Michel, Order of Things: An Archaeology of the Human Sciences (New York: Routledge, 1989).

Guattari, Felix, Chaosophy, trans. by David L. Sweet, Jarred Becker, and Taylor Adkins (Los Angeles, California: Semiotext(e), 2009).

Haraway, Donna, Modest Witness@Second Millennium. FemaleMan(C_Meets_OncoMouse ${ }^{\mathrm{TM}}$ : Feminism and Technoscience (New York and London, Routledge, 1997).

Hughes, Robert, "Bernard Stiegler, Philosophical Amateur, or, Individuation from Eros to Philia," in Diacritics, 42, 1(2014), 46-67.

Hui, Yuk, Recursivity and Contingency (London and New York: Rowman \& Littlefield, International, 2019).

(c) 2021 Virgilio A. Rivas

https://www.kritike.org/journal/issue 29/rivas december2021.pdf

ISSN 1908-7330

(c) BY-NC-ND 
Archives of the Future: Remarks on the Concept of Tertiary Protention (Gutenberg: Landsarkivet I Göteborg, 2018).

Kant, Immanuel, Critique of Pure Reason, trans. by Werner Pluhar (Indianapolis and Cambridge: Hackett Publishing Company, Inc., 1996).

Latour, Bruno, "Why Has Critique Run out of Steam? From Matters of Fact to Matters of Concern," in Critical Inquiry, 30, 2004. "Is This a Dress Rehearsal? Critical Inquiry, 47, (2020).

Monahan, Torin, and Rodolfo D. Torres, "Schools Under Surveillance," in Surveillance Studies: A Reader, ed. by Torin Monahan and David Murakami Wood, 204-208 (Oxford: Oxford University Press, 2018).

Prodnik, Jernej, "3C: Commodifying Communication in Capitalism," in Marx in the Age of Digital Capitalism, ed. by Christian Fuchs and Vincent Mosco, 233-321 (Brill: Leiden and London, 2016).

Roden, David, Posthuman Life: Philosophy at the Edge of the Human (London and New York: Routledge).

Searle, Adam and Jonathan Turnbull, "Resurgent Natures? More-thanHuman Perspectives on COVID-19," in Dialogues in Human Geography, 10 (2020).

Stiegler, Bernard, "Elements for a General Organology," trans. by Daniel Ross, in Derrida Today, 13 (2020). Nanjing Lectures: 2016-2019, trans. by Daniel Ross (London: Open Humanities Press, 2020). Neganthropocene, ed. and trans. by Daniel Ross (London: Open Humanities Press, 2018). "Kant, Art, and Time," trans. by Stephen Berker, with Arne De Boever, in boundary 2, 44 (2017).

"The New Conflict of the Faculty and Functions: Quasi-Causality and Serendipity in the Anthropocene," trans. by Daniel Ross, in Qui Parle, 26 (2017).

"The Quarrel of the Amateurs," trans. by Robert Hughes, in boundary 2, 44 (2017).

"The Proletarianization of Sensibility," in Boundary 2, 44 (2017).

, Automatic Society. Vol. 1. Future of Work, trans. by Daniel Ross

(Cambridge: Polity Press, 2016). What Makes Life Worth Living, trans. by Daniel Ross (Cambridge:

Polity Press, 2013).

Technics and Time, Vol. 2: Disorientation, trans. by Stephen Barker

(Stanford California: Stanford University Press, 2009). Acting Out, trans. by Daniel Barison, Daniel Ross, and Patrick Crogan (Stanford, California: Stanford University Press, 2009). 


\section{ON THE AMATEUR AND THE CRITIC}

Technics and Time, Vol. 1. The Fault of Epimetheus, trans. by Richard Beadsworth and George Collins (Stanford, California: Stanford University Press, 1998).

Sturman, Susan, “On Black-boxing Gender: Some Social Questions for Bruno Latour." Social Epistemology, 20 (2006).

Zuboff, Shoshana, The Age of Surveillance Capitalism: The Fight for A Human Future at the New Frontier of Power (New York: Public Affairs, 2019). 